\title{
Following the Structure and Reactivity of Tuncbilek Lignite during Pyrolysis and Hydrogenation
}

Arzu Kanca ${ }^{\mathrm{a}, \mathrm{b}}$, Matthew Dodd ${ }^{\mathrm{c}}$, Jeffrey A. Reimer ${ }^{\mathrm{c}}$, and Deniz $\underline{\operatorname{Uner}}^{\mathrm{a}}$

a Department of Chemical Engineering, Middle East Technical University, 06800, Cankaya, Ankara, Turkey

${ }^{\mathrm{b}}$ Department of Chemical Engineering, Ataturk University, 25240, Erzurum, Turkey.

${ }^{\mathrm{c}}$ Department of Chemical and Biomolecular Engineering, University of California, Berkeley, 94720, CA, USA

\section{Abstract}

Combustion, pyrolysis and hydropyrolysis reactivity of Tuncbilek lignite was monitored by Temperature Programmed Pyrolysis (TPP) under pure nitrogen flow, Temperature Programmed Oxidation (TPO) under air flow and Temperature Programmed Hydrogenation (TPH) under hydrogen flow at atmospheric pressure in a packed bed reactor.The structure of the organic and inorganic components were analyzed by NMR spectroscopy and XRD. Only methane and hydrogen were the main products of TPP while small amounts of $\mathrm{CO}$ and $\mathrm{CO}_{2}$ were also observed. Solid-state ${ }^{1} \mathrm{H}$ and ${ }^{13} \mathrm{C}$ CPMAS and $1 \mathrm{H}$ liquid Nuclear Magnetic Resonance (NMR) Spectroscopy of the pristine lignite, as well as tar and char products of pyrolysis and hydrogenation (hydropyrolysis), revealed similar tar compositions. TGA of pyrolysis chars indicated that there were more residual volatiles in hydropyrolysis char in comparison to pyrolysis char. Elemental analysis of pyrolysis and hydropyrolysis chars revealed that $25 \%$ of sulfur was lost during pyrolysis, whereas $>90 \%$ of sulfur was lost during hydropyrolysis indicating efficiency of atmospheric pressure hydropyrolysis for both desulfurization and tar production. Volatile matter and fixed carbon, mostly aromatic, gave rise to distinct oxidation peaks during TPO. The oxidation peak due to volatiles was missing from TPO of pyrolysis char as well as from organic contents determined NMR spectroscopy. Keywords: Tuncbilek lignite, sulfur, coal characterization, pyrolysis, hydrogenation, tar, ${ }^{1} \mathrm{H}$ NMR, ${ }^{13}$ C CPMAS NMR.

\section{1 | P a g e}

(C) 2016. This manuscript version is made available under the Elsevier user license http://www.elsevier.com/open-access/userlicense/1.0/ 


\section{Introduction}

$22.5 \%$ of the worlds recoverable coal reserves are lignite, the youngest form of coal [1]. Lignite reserves of Turkey constitute $1.6 \%$ of the total known world reserves. These low rank coals are generally high in ash and sulfur content yet low in calorific value, and are mainly used for electricity production. Therefore the chemistry and process engineering associated with the use of lignite for energy production remains an important research endeavor. Indeed, many of the basic research opportunities in coal science were identified in 1979 [2], yet remain unfulfilled due to the unsteady flows of research funding driven by global changes in the world economy. The authors in 1979 [2] stated that, "The technology bases for utilizing coal directly by combustion and for the conversion of coal to liquids and gases are available. However, in our opinion, considerable improvements in overall thermal efficiency, hydrogen utilization and to meet strict environmental requirements are needed.... New and better processes will develop as a result of the breakthroughs in our understanding of the chemistry of coal utilization and these breakthroughs will necessarily come from a better understanding of coal".

Coal is composed of organic (volatile and fixed carbon) and inorganic (ash) fractions [3, 4]. During the pyrolysis, gasification and/or liquefaction processes, the more reactive volatile and aliphatic carbon fractions in the structure are removed at relatively low temperatures. The remainder is coal char having highly ordered structure and less reactivity. The decrease in char reactivity is generally considered to be due to the decrease in both the surface area and the number of active sites during heating [5-9]. Since the physical and chemical properties of coal determine its processing fate, a detailed characterization of coal decomposition products is very important prior to designing coal carbonization, oxidation, and gasification and/or liquefaction processes. 
A variety of characterization techniques are currently used to provide reliable information about the coal decomposition products and their reactivity. Gupta suggested that classical coal analyses (proximate, ultimate and Eschka) do not provide sufficient information about the relation between coal structure and reactivity due to the assumed homogenous structure of coal [10]. Fourier transform infrared (FTIR) and ${ }^{13} \mathrm{C}$ NMR spectroscopy prove to be useful to describe the organic structure of coal [10-15]. X Ray Fluorescence (XRF) is used to identify the mineral constituents and their amounts while the reactivity of mineral components in the coal can be estimated through the structural changes observed by X Ray Diffraction (XRD) [13].

NMR methods have been used since 1960 to quantify the coal matrix. Brown and Ladner used proton NMR to indicate the aromatic fraction of coal derived materials in 1960 [16-18]. Modern pulse and Fourier Transform NMR techniques have been used since 1970 in order to determine the organic structure determination [11, 19-21]. In addition to coal characterization, NMR spectroscopy is also very useful for the detailed analysis of coal liquefaction products $[22,23]$

The objectives of the present study are to explore the relationship between Tuncbilek lignite chemical structure and its reactivity by monitoring its pyrolysis and hydrogenation products. The heterogeneous structure of coal and its residues were monitored by NMR spectroscopy while temperature programmed oxidation of coal was used to determine the reactivity of coal residue obtained during the pyrolysis and hydrogenation. The changes in sulfur composition in Tuncbilek lignites during pyrolysis and hydrogenation were also determined.

\section{Materials and methods}

\subsection{Preparation of coal sample}

Coal samples were donated from Turkish Coal Enterprises (TKI) Tuncbilek Lignite Establishment in Turkey. To obtain a representative sample, $25 \mathrm{~kg}$ coal was crushed in a 
grinder, spread on a flat surface, and divided into four equal parts. After two parts were discarded, the remaining parts were mixed and the same process was repeated until $1 \mathrm{~kg}$ sample remained. This remaining sample was sieved to obtain particles of maximum $150 \mu \mathrm{m}$.

\subsection{Reactor system}

Semi-batch processing of coal was performed in a home built reactor system connected to a HP 5890 gas chromatograph equipped with the Porapak Q column. Approximately $500 \mathrm{mg}$ of a lignite sample was placed in a $1 / 4$-inch quartz reactor and fastened by quartz wool at both ends. The reactor was placed in a home built temperature-controlled furnace. All of the gases used in this study were procured from Oksan (99.99\% purity). Pyrolysis and oxidation experiments were conducted in the temperature range of $40-800{ }^{\circ} \mathrm{C}$ with a heating rate of 5 $\mathrm{K} / \mathrm{min}$ under $200 \mathrm{cc} / \mathrm{min} \mathrm{N}_{2}$ and air flow, respectively. Hydrogenation of Tuncbilek lignite was carried out by flowing $50 \mathrm{cc} / \mathrm{min}$ of a $\mathrm{H}_{2}-\mathrm{N}_{2}$ mixture, keeping the rest of the experimental conditions the same. Gas analyses during pyrolysis and oxidation processes were performed by monitoring $\mathrm{GC}$ signals for $\mathrm{H}_{2}, \mathrm{CH}_{4}$, and $\mathrm{CO}_{2} . \mathrm{H}_{2} \mathrm{~S}$ formed during hydrogenation reactions was collected in a sulfur trap by passing the reactor effluent gases through a wash bottle filled with saturated $\mathrm{Pb}$-acetate solution. Owing to complications that can arise from $\mathrm{H}_{2} \mathrm{~S}$ and gases condensing in the wash bottle, GC analysis was not performed during hydrogenation experiments. Quartz wool was placed at the exit of the reactor to collect tar. Some of the NMR measurements were performed using tar deposited on the reactor walls. Both samples yielded similar results.

\subsection{Coal analyses}

\section{Proximate, ultimate and Eschka analyses of lignite}

Three identical samples were used for the proximate and ultimate analyses, and the average results of the three measurements were reported. In proximate analysis, moisture, volatile 
matter, and ash composition of the lignite samples were determined according to ASTM D3173, D-3174, and D-3175 standards, respectively. For the ultimate analysis, LECO-CHNS932 analyzer was used to determine the carbon, hydrogen, nitrogen, and sulfur contents of the lignite. The sulfur composition was also determined from Eschka method [24].The heating value of the lignite was measured with a bomb calorimeter (Gallenkamp Autobomb, CAB001.AB1.C).

\section{Ray analyses}

X-ray Fluorescence (XRF) spectroscopy (Rigaku ZSX Primus II) was used to determine the mineral contents of lignite and its ash after combustion. The sample was mixed with a wax binder in a weight ratio of $4: 1$ and the mixture was then pressed at 15 tons into $32 \mathrm{~mm}$ diameter pellets before analysis. The XRD experiment was performed with a Philips model PW1840 (1729) X-ray diffractometer using Ni filtered $\mathrm{Cu}-\mathrm{K} \alpha 945$ radiation $(\mathrm{l}=1.5405 \AA)$ operating at $30 \mathrm{kV}$ and $15 \mathrm{~mA}$. Scan rate was selected as 0.05 degrees $/ \mathrm{s}$.

\section{Thermal Analyses}

Thermal Gravimetric Analysis (TGA) (Shimadzu DTG 60H) experiments were conducted in the temperature range between $25-900{ }^{\circ} \mathrm{C}$ with a heating rate of $10 \mathrm{~K} / \mathrm{min}$ under $60 \mathrm{cc} / \mathrm{min} \mathrm{N}_{2}$ flow to determine the moisture and volatile content and $60 \mathrm{cc} / \mathrm{min}$ air flow to determine the amount of total combustibles.

\section{Solid state NMR}

${ }^{1} \mathrm{H}$ MAS and ${ }^{13} \mathrm{C}$ Cross Polarization Magic Angle Spinning (CPMAS) measurements were performed using an Apollo spectrometer (Tecmag, Houston, TX). The proton channel was tuned to $299.79 \mathrm{MHz}$ while $75.39 \mathrm{MHz}$ was employed for carbon. A $4 \mathrm{~mm}$ Doty Scientific probe (DSI-1231) capable of spinning the samples up to $15 \mathrm{kHz}$ was used for both ${ }^{1} \mathrm{H}$ MAS and ${ }^{13} \mathrm{C}$ CP-MAS measurements. 


\section{Liquid NMR}

Standard ${ }^{1} \mathrm{H}$ NMR measurements were conducted on a Bruker $400 \mathrm{MHz}$ Avance spectrometer equipped with a $\mathrm{BBO}$ probe. DMSO $\left(\left(\mathrm{CD}_{3}\right)_{2} \mathrm{SO}\right)$ was used to extract liquid components from char, tar and the lignite for analysis. Solid samples were suspended in DMSO and sonicated in an ultrasonic bath for $60 \mathrm{~min}$ at around $45^{\circ} \mathrm{C}$. The samples were left overnight at room temperature for further extraction and solid settling; liquids dissolved in DMSO were taken for ${ }^{1} \mathrm{H}$ NMR.

\section{Results}

\subsection{Coal Analyses}

The results from the proximate analysis and elemental analysis of Tuncbilek lignite on air dried basis are presented in Table 1 . Volatile matter of coal sample was $\sim 28 \%$, while ash content in coal was determined to be $38 \%$ by weight. The results of ultimate analysis in Table 1 indicate that the relative amount of carbon is $37.7 \pm 0.7 \mathrm{wt} \%$. Hydrogen and nitrogen contents of coal are $3.6 \pm 0.1$ and $1.6 \pm 0.1 \mathrm{wt} \%$, respectively, while sulfur content is $5.4 \pm 0.6$

$w t \%$. The total amount of sulfur was determined by Eschka method as $3.9 \pm 0.2 \%$. In addition to sample heterogeneity, the difference between the sulfur amounts reported by two different methods of sulfur analysis most probably stems from the differences in the temperatures used. In ultimate analysis, coal is combusted at $925^{\circ} \mathrm{C}$, while in Eschka analysis combustion temperature was $825^{\circ} \mathrm{C}$. Furthermore, the heating value of lignite sample was determined as $3680 \pm 60 \mathrm{cal} / \mathrm{g}$. The major inorganic components present in Tuncbilek lignite, and its ash, were determined by XRF and are shown in Table 2. The XRF analysis reports the relative amounts of the elements detected in the samples in terms of oxides in their highest 
oxidation state. The relative ratios of $\mathrm{SiO}_{2}, \mathrm{Al}_{2} \mathrm{O}_{3}$ and $\mathrm{Fe}_{2} \mathrm{O}_{3}$ remained unchanged between the lignite and its ash. However, the amount of sulfur reported in terms of $\mathrm{SO}_{3}$ decreased significantly confirming largely combustible nature of the sulfur as reported in Table 1 . The results presented are consistent with the published reports of similar samples [25].

\subsection{TGA analyses under $\mathrm{N}_{2}$ and air flow}

The TGA of lignite under $\mathrm{N}_{2}$ flow is shown in Figure 1 (top). $5 \%$ weight loss near $100{ }^{\circ} \mathrm{C}$ corresponds to the relative amount of moisture. The remaining $28 \%$ weight loss represents the volatile content of coal. The derivative curve of the weight loss indicated that maximum weight loss occurred at $450{ }^{\circ} \mathrm{C}$. TGA in air of the same sample is presented in Figure 1(bottom). The moisture content is consistent with the results obtained under $\mathrm{N}_{2}$ flow. The final percentage of mass $(\sim 38 \%)$ left in the pan after oxidation corresponds to ash. The ash, moisture, volatile and fixed carbon amounts determined from TGA are consistent with the proximate analysis results presented in Table 1.

\subsection{Temperature programmed pyrolysis (TPP) and temperature programmed oxidation (TPO) tests}

Temperature programmed pyrolysis and oxidation experiments were conducted in the temperature range of $40-800{ }^{\circ} \mathrm{C}$ under $200 \mathrm{cc} / \mathrm{min} \mathrm{N}_{2}$ and air flows in the semi-batch reactor system described in Section 2. $\mathrm{CH}_{4}, \mathrm{H}_{2}$, and $\mathrm{CO}_{2}$ were the main products observed during temperature-programmed experiments under $\mathrm{N}_{2}$ flow. The reactor furnace temperature was increased at a constant rate of $5 \mathrm{~K} / \mathrm{min}$. Since hot spots can be formed during the exothermic decomposition (resulting in differences between the temperature in the furnace and in the reactor), the data are presented with respect to time instead of temperature. Formation rates for $\mathrm{CH}_{4}, \mathrm{H}_{2}$ and $\mathrm{CO}_{2}$ are shown in Figure 2. The total amounts of methane, hydrogen and carbon dioxide were determined from the area under the curves and are presented in Table 3. The total amount of material accounted by the values reported in the first column of Table 3 
$\left(\mathrm{H}_{2}, \mathrm{CH}_{4}\right.$ and $\left.\mathrm{CO}_{2}\right)$ corresponds to $0.16 \mathrm{~g} / \mathrm{g}$ coal. This is in agreement with the $28 \mathrm{wt} \%$ volatiles measured by proximate analysis and TGA considering that $C_{n}$ compounds with $n \geq 2$ were not measured in the gas analysis.

Gas formation rates for $\mathrm{CH}_{4}, \mathrm{H}_{2}$, and $\mathrm{CO}_{2}$ were also monitored during temperatureprogrammed-oxidation under air flow. Very small amounts of methane and hydrogen were detected at the earlier phases of the reaction (not shown). $\mathrm{CO}_{2}$ formation rates under air flow are shown in Figure 3 for a pristine lignite sample (b); pyrolysis data are shown in (a) for comparison. On the same figure, the $\mathrm{CO}_{2}$ evolution rates from TPO of the pyrolysis product are also shown (Figure $3 \mathrm{c})$. Integrated amounts of gaseous products $\left(\mathrm{CH}_{4}, \mathrm{H}_{2}\right.$, and $\left.\mathrm{CO}_{2}\right)$ are given in Table 3. The amount of $\mathrm{CO}_{2}$ formed during oxidation corresponds to about $0.4 \mathrm{~g} \mathrm{C} / \mathrm{g}$ coal, consistent with the elemental analysis (Table 1).

The results presented in Figure 3 indicate different events taking place in different temperature ranges: volatile matter combustion occurs at around $250{ }^{\circ} \mathrm{C}$; combustion of the fixed carbon takes place in two different combustion processes as indicated by peaks at 350 and $450{ }^{\circ} \mathrm{C}$. These results suggest that combustion is a strong function of the chemical identities of the compounds found in the coal. These chemical constituents were therefore probed via ${ }^{1} \mathrm{H}$ and ${ }^{13} \mathrm{C}$ NMR spectroscopy by comparing spectra from as-received coal with pyrolysis, hydrogenation and oxidation residues.

\section{4. $\quad{ }^{1} \mathrm{H}$ and ${ }^{13} \mathrm{C}$ (CP) MAS-NMR Spectroscopy}

As described above, ${ }^{13} \mathrm{C}$ NMR spectroscopy prove to be useful to describe the organic structure of coal [10-15] especially when it is possible to make quantitative analyses [26]. We therefore analyzed unprocessed coal, its pyrolysis and hydrogenation residues using ${ }^{1} \mathrm{H}$ MAS and ${ }^{13} \mathrm{C}$ CP-MAS NMR. The ${ }^{1} \mathrm{H}$ MAS NMR spectrum of unprocessed coal is presented in Figure $4 \mathrm{a}$, along with the ${ }^{1} \mathrm{H}$ NMR spectrum of the pyrolysis residue in Figure $4 \mathrm{~b}$ (peaks are

normalized with respect to their scan counts). The ${ }^{1} \mathrm{H}$ MAS NMR spectrum of unprocessed 
coal was fit to Lorentzian curves yielding two major peaks at approximately $6.1 \mathrm{ppm}$ and 0.5 ppm. In the case of the unprocessed lignite, the peak at $\sim 1.0 \mathrm{ppm}$ is assigned to aliphatic protons in the range of $0.5-5 \mathrm{ppm}[22,27]$ and $6.1 \mathrm{ppm}$ peak represents aromatic protons [2729]. The ${ }^{1} \mathrm{H}$ MAS NMR spectrum of pyrolysis char revealed two peaks at (-0.7 and $\left.6.5 \mathrm{ppm}\right)$. The most probable assignment of the $-0.7 \mathrm{ppm}$ signal is $-\mathrm{OH}$ groups while $6.5 \mathrm{ppm}$ signal is assigned to aromatic protons. Moreover, no proton signal was detected above the background for the hydrogenation residues. Figure $4 \mathrm{c}$ shows the ${ }^{1} \mathrm{H}$ NMR analysis of tar extracted during hydrogenation. The ${ }^{1} \mathrm{H}$ peaks from this material are consistent with the shifts observed in the pristine coal and the pyrolysis char.

The ${ }^{13} \mathrm{C}$ CP-MAS NMR spectrum of the unprocessed Tuncbilek lignite shown in Figure 5a consists of two main signals that are associated with the aliphatic and aromatic hydrocarbon fractions of the lignite sample. In the aliphatic region the intense peak at approximately 20 ppm originates from methyl $\left(-\mathrm{CH}_{3}\right)$ groups [28-33]. The largest peaks at 125 and $130 \mathrm{ppm}$ arise from protonated and non-protonated aromatic carbon structures, respectively [28-30, 32, 34-37]. The shoulders between 150 to $190 \mathrm{ppm}$ arise from oxygen bonded aromatic C-O (150165 ppm), carbonyl, and $\mathrm{NC}=\mathrm{O}$ groups $(165-190 \mathrm{ppm})[23,28,32,37-40]$. Figure $5 \mathrm{~b}$ affirms our contention that the aliphatic portions of the pyrolysis residue are absent (e.g., the trends seen in going from Figure $4 \mathrm{a}$ to $4 \mathrm{~b}$ ). The changes in aromatic carbon region of the ${ }^{13} \mathrm{C}$ spectra (100-200 ppm) are largely interpreted as due to changes in the ${ }^{13} \mathrm{C}$ natural linewidths owing to the inhomogeneity of the samples and/or the presence of unpaired electrons associated with minerals or coal defects. The quantification of the ${ }^{13} \mathrm{C}$ CP-MAS data for the lignite shown in Figure 5.a indicated that $35 \%$ of the signal originated from aliphatics (at $27 \mathrm{ppm}$ ) and $65 \%$ was due to aromatics (at $131 \mathrm{ppm}$ ). The corresponding NMR spectrum of pyrolysis char (Figure 5.b) did not reveal any aliphatic carbons. The tar extracts (Figure 5c) show the highest resolution, with peaks at 155 and $166 \mathrm{ppm}$ representing oxygenated aromatic carbon 
structures. Vestiges of these features are present in the lignite (unprocessed) coal, whereas they are largely broadened in the spectrum from the pyrolysis residue.

\subsection{Effects of pyrolysis and hydrogenation on sulfur content}

The results of the elemental analysis before and after pyrolysis and hydrogenation processes presented in Table 4 indicate that sulfur contents of lignite samples were significantly reduced after hydrogenation. Other important implications from Table 4 are i; the decrease in hydrogen content during pyrolysis verifies the utilization of inherent hydrogen for sulfur

removal; ii, relative amounts of carbon in residues were preserved; and iii, both hydrogen and nitrogen composition also decreased under pure hydrogen flow.

Sulfur removal was monitored by XRD via analyses of the characteristic peaks associated with pyrite. XRD patterns of cubic pyrites shown $2 \theta$ peaks at $28.8,33.2,37.2,40.9,47,56.2$, $59.9,64.4^{\circ}$ (JCPDS CARD NO 42-1340) [41-45]. The X-ray diffraction patterns of pyrolysis and hydrogenation residues of Tuncbilek lignite shown in Figure 6 reveal the loss of these characteristic pyrite peaks after pyrolysis and hydrogenation. While the quartz $(2 \theta \sim 26.8,20.9$, $50.4,37.2,39.7^{\circ}$ ) peaks remained uninfluenced after pyrolysis and hydrogenation, the kaolinite $\left(2 \theta \sim 12.5,20.3,24.9,36.1,38.6^{\circ}\right)[46]$ peaks disappeared after the aforementioned processes. Appearance of $\mathrm{Fe}(110)$ peak at $2 \theta=44.6^{\circ}$ confirmed the elimination of pyrite to form metallic Fe during hydrogenation $[47,48]$.

\section{Discussion}

Pyrolysis is the thermal decomposition of organic compounds in an oxygen-free atmosphere and can be considered as the initial stage of combustion, liquefaction, and gasification [40, 49-51]. During our experiments, the oxygen free atmosphere was established by a nitrogen sweep over a packed bed of lignite. The rates of hydrogen, methane and carbon dioxide evolution during TPP of Tuncbilek lignite are shown in Figure 2. $\mathrm{CO}_{2}$ production 
commenced at around $200{ }^{\circ} \mathrm{C}$ during pyrolysis and is attributed to the decomposition of aliphatic carboxylic acids [50]. Cracking of complex coal structure into light hydrocarbon fragments, $\mathrm{CO}_{2}$ and water is the second step of pyrolysis taking place up to $500{ }^{\circ} \mathrm{C}$. Formation of methane was observed at around $300{ }^{\circ} \mathrm{C}$, followed by hydrogen at around $350{ }^{\circ} \mathrm{C}$. These temperatures are consistent with the reports in the literature that $\mathrm{H}_{2}$ evolution begins at approximately $300{ }^{\circ} \mathrm{C}$ with the destruction of the $\mathrm{H}_{2}$ rich part of the coal [50]. It must be noted that the pyrolysis product distribution depends strongly upon temperature [52]. Slow heating rates increase the amounts of volatiles and tar as well as their formation temperatures [53], indicating significant heat and mass transfer limitations during the pyrolysis process.

The $\mathrm{CO}_{2}$ evolution rates during TPO of pristine lignite and the char produced after pyrolysis suggest three different $\mathrm{CO}_{2}$ formation mechanisms (Figure 3). Oxidation of aliphatic compounds takes place at low temperatures during oxidation of the pristine lignite based upon the following evidences. First, the low temperature combustion peak was absent from the TPO of the pyrolysis residue. Second, all of the aliphatic compounds present in pristine coal were eliminated after pyrolysis as indicated from ${ }^{1} \mathrm{H}$ and ${ }^{13} \mathrm{C}$ CP-MAS NMR data (Figures 4 and 5). Third, the amounts of evolved methane and hydrogen during pyrolysis $(0.16 \mathrm{~g} / \mathrm{g}$ coal $)$ determined by gas chromatography corresponds well with to amount of volatile compounds measured by TGA (28 wt\%). Remaining differences are attributed to the $\mathrm{C}_{2}$ and greater carbon-containing volatile compounds that could not be analyzed due to our experimental limitations.

Char combustion commences at $\sim 500^{\circ} \mathrm{C}$ (Figure 3, b-c) and exhibits a consistent pattern of a large $\mathrm{CO}_{2}$ formation followed by two relatively slower processes indicated by smaller $\mathrm{CO}_{2}$ evolution peaks for both pristine lignite samples and pyrolysis product. The total area under the peaks of the pristine lignite were evaluated and found to be in good agreement with the amount of carbon in the pristine coal (Table 3). 
Direct hydrogenation of coal has been known since early $20^{\text {th }}$ century [54-57]. In general, hydrogenation is performed at elevated pressures $(\sim 200 \mathrm{~atm})$ and $400^{\circ} \mathrm{C}$ to produce pitch-like hydrocarbon that crack to light hydrocarbons at $450{ }^{\circ} \mathrm{C}$ [55]. Coal tar is used to produce benzene, toluene, and xylene, while the pitch fraction of tar is the raw material for the production of activated carbon, graphite, and carbon fiber [58]. The product distribution depends on the type of coal, liquefaction temperature, type of catalyst, and hydrogen donor [54]. The efficiency of the hydrogenation process was found to be higher for the low rank coals [56]. The reason for this is presumed to be that since the $\mathrm{H} / \mathrm{C}$ ratio is higher in the younger coals, it is easier to break the methylene bridge and alkyl side chain bonds during hydrogenation $[55,56,59]$. It is also important to note that aromaticity of the coal liquid increases with increasing liquefaction temperature [60]. The catalytic effects of metallic oxides present as inorganic compounds prevent the polymerization of the hydrocarbon during the heating process [55]. High hydrogen pressure is required to increase the reaction yield, and this is the main challenge of the process. Furthermore, high $\mathrm{H}_{2}$ pressure was reported to stabilize the liquid phase and prevents coke formation. In this study, atmospheric pressure hydropyrolysis was investigated.

In the work reported herein, hydrogenation/hydropyrolysis was carried out by flowing pure hydrogen gas at atmospheric pressure over a packed bed of lignite. The gaseous products of hydrogenation were not followed quantitatively by a gas chromatograph due to the interferences from a large peak of hydrogen as a reactant and sweep gas, and other complications due to the presence of sulfur, discussed in detail in the experimental part. The remaining char in the packed bed and tar collected at the exit of the reactor were analyzed by elemental analysis and NMR spectroscopy. 
The char resulting from hydrogenation exhibited no ${ }^{1} \mathrm{H}$ signal (and correspondingly no ${ }^{13} \mathrm{C} \mathrm{CP}$ MAS signal), indicating that almost all of the hydrogen and hydrogen containing carbon compounds were removed during hydrogenation. Conversely, tar collected at the end of the reactor exhibited distinct peaks for aromatic and oxygenated compounds (Figures 4 and 5). The position of the peaks in tar and the features observed in the ${ }^{13} \mathrm{C}$ CPMAS NMR spectra for the pristine lignite and the pyrolysis residue indicate that it was possible to remove oligomers from the structure by hydrogenation and collected as tar.

A comparison of the data presented in Figures 2-5 also reveals the mutual correspondence of aliphatic compounds with the early $\mathrm{CO}_{2}$ evolution during oxidation: after pyrolysis, the oxidation experiment did not exhibit the low temperature peak. The ${ }^{13} \mathrm{C}$ CP MAS NMR data (Figure 5b) of pyrolysis residue did not exhibit any signal corresponding to the aliphatic carbons (28 ppm), further supporting our argument. The ${ }^{13} \mathrm{C}$ CP MAS NMR peak assigned to the aromatic compounds lost the shoulder at $150 \mathrm{ppm}$ after pyrolysis. Post hydrogenation residue did not give rise to a detectable ${ }^{13} \mathrm{C}$ CP MAS NMR signal due to the absence of ${ }^{1} \mathrm{H}$ signal. But the TGA and elemental analysis data reported in Table 4 for post hydrogenation residue indicate $38 \%$ weight loss, $38.8 \mathrm{wt} \% \mathrm{C}$ and $0.7 \mathrm{wt} \% \mathrm{H}$.

The similarity of the aromatic peak line shapes of tar and unprocessed lignite in ${ }^{13} \mathrm{C}$ NMR spectra (Figure 5) is noteworthy. This fact is interpreted to be an evidence of the presence of chemical bonds in coal structure which can be broken in the presence of hydrogen. The absence of any hydrogenated carbon residues in ash after hydrogenation step further confirms that Tuncbilek lignite can easily be hydrogenated to gaseous and liquid products. As seen in Figure 4 and 5, similarity of NMR spectra of tar and lignite in aromatic region further suggests that lignite framework is composed of aromatic oligomers, which can be cracked relatively easily in the presence of $\mathrm{H}_{2}$. A visual examination of the tar condensed at the reactor exit, after pyrolysis and hydrogenation revealed that hydrogenation resulted on more tar build 
up than pyrolysis. Due to very small amounts of samples used in our experiments, quantification of the tar collected on the quartz wool placed at the end of the reactor could not be performed. However, the TGA in $\mathrm{N}_{2}$ of the pyrolysis char and hydropyrolysis char (Table 4) indicate that hydropyrolysis is more efficient in the removal of the volatiles. Tar collected on the quartz wool was also extracted in DMSO for Liquid ${ }^{1} \mathrm{H}$ NMR analysis. The results are presented in Figure 7. The assignment of the peaks and their relative intensities were consolidated in Table 5 [22, 61-63]. The broad peak in the aromatics region of the pyrolysis tar extract is more symmetric whereas hydrogenation tar extract exhibit broad features. Furthermore, hydropyrolysis char contains fewer aliphatic bonds than pyrolysis char and the DMSO extractable components are mostly aromatic compounds (Table 5).

It is important to note the role of the catalytic effects of the coal minerals during pyrolysis and hydrogenation. Fe was present in the form of pyrite in Tuncbilek lignite. Pyrite is known to catalyze coal oxidation, liquefaction, and gasification reactions [64-67]. The reduction reaction of pyrite with $\mathrm{H}_{2}$ increases the amount of volatiles. Iron sulfide $(\mathrm{FeS})$ produced by pyrite decomposition has a higher reactivity than pyrite and it increases the hydrogenation reactivity by holding the activated hydrogen on the iron sulfide surface [67]. Alkaline (Na and $\mathrm{K})$ and alkaline earth $(\mathrm{Ca}$ and $\mathrm{Mg})$ metal species and transitional metals $(\mathrm{Fe}$ and $\mathrm{Ni})$ are the most common catalysts [68]. The removal of these minerals in coal inorganic structure were reported to decrease the organic sulfur removal due to the decrease in pyrolytic conversion [65].

The effect of hydrogenation on the sulfur content of the coal and on the aromatic content of the coal was also investigated. After processing in pure hydrogen, $>90 \%$ of sulfur in the pristine coal was removed (Table 4). The data presented in Table 4 reveal that the difference between the ash content of the pyrolysis char (59\% ash) and hydrogenation residue (62\% ash) and their corresponding sulfur contents (3.9 versus $0.5 \%$ respectively) agree very well. Noting 
that the process was carried out under atmospheric pressure hydrogen, elimination of $>90 \%$ of sulfur is remarkable. Furthermore, most of the volatiles and oxygenates and some of the aromatic compounds were also removed. TGA data compiled in Table 4 indicates that, after hydropyrolysis, only $5 \%$ of the sample constituted the volatiles, in comparison to the appreciable amount of volatiles present (19\%) in the pyrolysis char. Cracking and removing of $\mathrm{O}_{2}, \mathrm{~S}$ and $\mathrm{N}_{2}$ are the desired reactions in coal-to-liquids processes [69]. Although Mo and Sn compounds were considered as liquefaction catalysts, due to their regeneration problems, Fe compounds became more popular. The most favorable coal liquefaction catalysts were reported as the oxide and sulfide forms of transition metals such as, $\mathrm{Mo}, \mathrm{W}, \mathrm{Co}, \mathrm{Sn}, \mathrm{Ni}, \mathrm{Fe}$ [57]. Greater abundance of Fe in pristine coal and in ash of our Tuncbilek samples (Table 2) is probably the underlying reason of the high reactivity observed for Tuncbilek lignite during hydrogenation and pyrolysis.

The elemental analysis of pristine lignite, compared to the pyrolysis and hydrogenation residues, reveals significant amounts of sulfur loss after both processes (Table 4). XRF results presented in Table 2 also indicated the loss of significant amounts of sulfur from the structure after combustion. According to the results of Eschka analysis, sulfur was mainly present as pyrite in the pristine lignite (Table 1). The elimination of pyrite peaks from the pristine lignite upon pyrolysis and hydrogenation accompanied by the appearance of Fe (110) peak was clearly observed in the XRD patterns, shown in Figure 6. Pyrolysis is accepted to be an important desulfurization step [22, 70-72], with the major desulfurization reaction being pyrite-organic coal matrix interactions resulting in hydrogen sulfide evolution. Pyrite may also be converted to $\mathrm{SO}_{2}$ when the oxygen content of coal is high. Inorganic compounds, including $\mathrm{Na}$ and dolomite, do not improve either organic or inorganic sulfur removal. On the other hand, they prevent sulfur decomposition $[71,72]$. 
High amounts of sulfur present in the pristine brown coal assisted the hydrogenation and cracking process, giving rise to gaseous products as well as commercially valuable oxygenates and aromatics at low temperatures and under atmospheric hydrogen pressure. The role of pyrite and sulfur as catalysts for combustion reactions was implicit as increased oxidation temperatures of the hydrogenation char (not shown), deserving further systematic attention. In addition, further studies will also reveal whether atmospheric pressure hydrogenation of brown coals with large amounts of pyritic sulfur bear economical advantage when sulfur recovery and utilization is also integrated in the overall process.

\section{Conclusions}

${ }^{1} \mathrm{H}$ and ${ }^{13} \mathrm{C}$ NMR analyses, combined with TGA and semi batch combustion reactor measurements, revealed that hydrogenation can produce coal tar with an organic structure similar to the pristine lignite. $>90 \%$ of the sulfur in Tuncbilek lignite could be eliminated under atmospheric pressure hydrogen flow. After hydrogenation, the carbon residue and liquid products were essentially sulfur free. The rate of formation of $\mathrm{CO}_{2}$ due to pyrolysis char, monitored during temperature programmed oxidation reaction, did not change appreciably in the absence of volatiles, consistent with the results of TGA measurements.

\section{Acknowledgements}

The authors are grateful for Turkish Coal Enterprises for coal samples and partial financial support for this project. One of the authors (A.K.) is supported by the State Planning Organization under the auspices of OYP program and The Scientific and Technological Research Council of Turkey-BIDEB is another support for her abroad study. The authors extend their appreciation towards Turgut Aksakal for proximate and ESCHKA analysis; 
Veysi Helvaci and UC Berkeley College of Chemistry NMR Facility director Dr. Hasan Celik for their contributions towards liquid NMR data and Central Laboratory of ODTU for elemental analysis. The liquid NMR instrument used in this study was partially funded by the NSF grants (CHE-0130862,CHE-8703048) and the NIH grant (S10 RR 03353-01). 


\section{References}

[1] https://www.worldenergy.org/data/resources/resource/coal/ last accessed December 15, 2015. [2] M.L. Gorbaty, F.J. Wright, R.K. Lyon, R.B. Long, R.H. Schlosberg, Z. Baset, R. Liotta, B.G. Silbernagel, D.R. Neskora, COAL SCIENCE - BASIC RESEARCH OPPORTUNITIES, Science, 206 (1979) 1029-1034.

[3] A. Molina, F. Mondragon, Reactivity of coal gasification with steam and CO2, Fuel, 77 (1998) 18311839.

[4] Y. Sekine, K. Ishikawa, E. Kikuchi, M. Matsukata, A. Akimoto, Reactivity and structural change of coal char during steam gasification, Fuel, 85 (2006) 122-126.

[5] S. Kucukbayrak, H. Haykiri-Acma, A. Ersoy-Mericboyu, S. Yaman, Effect of lignite properties on reactivity of lignite, Energy Conversion and Management, 42 (2001) 613-626.

[6] B. Feng, S.K. Bhatia, J.C. Barry, Variation of the crystalline structure of coal char during gasification, Energy \& Fuels, 17 (2003) 744-754.

[7] A. Arenillas, F. Rubiera, C. Pevida, C.O. Ania, J.J. Pis, Relationship between structure and reactivity of carbonaceous materials, Journal of Thermal Analysis and Calorimetry, 76 (2004) 593-602.

[8] L.M. Lu, V. Sahajwalla, D. Harris, Coal char reactivity and structural evolution during combustion Factors influencing blast furnace pulverized coal injection operation, Metallurgical and Materials Transactions B-Process Metallurgy and Materials Processing Science, 32 (2001) 811-820.

[9] L.M. Lu, C.H. Kong, V. Sahajwalla, D. Harris, Char structural ordering during pyrolysis and combustion and its influence on char reactivity, Fuel, 81 (2002) 1215-1225.

[10] R. Gupta, Advanced coal characterization: A review, Energy \& Fuels, 21 (2007) 451-460. [11] G.E. Maciel, M.J. Sullivan, L. Petrakis, D.W. Grandy, C-13 NUCLEAR MAGNETIC-RESONANCE CHARACTERIZATION OF COAL MACERALS BY MAGIC-ANGLE SPINNING, Fuel, 61 (1982) 411-414.

[12] A.M. Vassallo, N.C. Lockhart, J.V. Hanna, R. Chamberlain, P.C. Painter, M. Sobkowiak, INFRARED AND NUCLEAR-MAGNETIC-RESONANCE SPECTROSCOPY OF DENSITY FRACTIONS FROM CALLIDE COAL, Energy \& Fuels, 5 (1991) 477-482.

[13] J.V. Ibarra, R. Moliner, COAL CHARACTERIZATION USING PYROLYSIS FTIR, Journal of Analytical and Applied Pyrolysis, 20 (1991) 171-184.

[14] Y. Adachi, M. Nakamizo, STRUCTURAL PARAMETERS OF ARGONNE COAL SAMPLES - SOLID-STATE C-13 NMR-SPECTROSCOPY, Advances in Chemistry Series, (1993) 269-279.

[15] L.Q. Wang, Y.H. Dun, X.N. Xiang, Z.J. Jiao, T.Q. Zhang, Thermodynamics research on hydrogen production from biomass and coal co-gasification with catalyst, International Journal of Hydrogen Energy, 36 (2011) 11676-11683.

[16] H.L. Retcofsky, INVESTIGATION OF CHEMICAL-STRUCTURE OF COAL BY NUCLEAR MAGNETICRESONANCE AND IR SPECTROMETRY, Applied Spectroscopy, 31 (1977) 116-121.

[17] H.L. Retcofsky, F.K. Schweighardt, M. Hough, DETERMINATION OF AROMATICITIES OF COAL DERIVATIVES BY NUCLEAR MAGNETIC-RESONANCE SPECTROMETRY AND BROWN-LADNER EQUATION, Analytical Chemistry, 49 (1977) 585-588.

[18] H.L. Retcofsky, D.L. Vanderhart, C-13-H-1 CROSS-POLARIZATION NUCLEAR MAGNETICRESONANCE SPECTRA OF MACERALS FROM COAL, Fuel, 57 (1978) 421-423.

[19] E. Furimsky, J. Ripmeester, CHARACTERIZATION OF CANADIAN COALS BY NUCLEAR MAGNETICRESONANCE SPECTROSCOPY, Fuel Processing Technology, 7 (1983) 191-202.

[20] A.H. Fawcett, J. Grimshaw, J. Trochagrimshaw, F. Donnelly, B.J. Say, CP MAS NMR-SPECTRA OF SAMPLES FROM THE ULSTER LIGNITE DEPOSITS, Fuel, 69 (1990) 415-420.

[21] D.E. Axelson, SOLID-STATE C-13 NUCLEAR-MAGNETIC-RESONANCE STUDY OF CANADIAN COALS, Fuel Processing Technology, 16 (1987) 257-278.

[22] P. Wang, L. Jin, J. Liu, S. Zhu, H. Hu, Analysis of coal tar derived from pyrolysis at different atmospheres, Fuel, 104 (2013) 14-21.

[23] T. Yoshida, M. Sasaki, K. Ikeda, M. Mochizuki, Y. Nogami, K. Inokuchi, Prediction of coal liquefaction reactivity by solid state C-13 NMR spectral data, Fuel, 81 (2002) 1533-1539. 
[24] J.G. Speight, Handbook of coal analysis, Hoboken Wiley-Interscience

, New Jersey, 2005.

[25] E. Tuncali, B. Ciftci, N. Yavuz, S. Toprak, A. Koker, H. Aycik, Z. Gencer, N. Sahin, Chemical and Technological Properties of Turkish Tertiary Coals, Mineral Research \& Exploration General Directorate (MTA) Publications, (2002) 252-263.

[26] J.D. Mao, W.G. Hu, K. Schmidt-Rohr, G. Davies, E.A. Ghabbour, B.S. Xing, Quantitative characterization of humic substances by solid-state carbon-13 nuclear magnetic resonance, Soil Science Society of America Journal, 64 (2000) 873-884.

[27] H. Sutcu, I. Toroglu, S. Piskin, Structural characterization of oil component of high temperature pyrolysis tars, Energy Sources, 27 (2005) 521-534.

[28] L. Delarosa, M. Pruski, D. Lang, B. Gerstein, P. Solomon, CHARACTERIZATION OF THE ARGONNE PREMIUM COALS BY USING H-1 AND C-13 NMR AND FT-IR SPECTROSCOPIES, Energy \& Fuels, 6 (1992) 460-468.

[29] Y. Li, X.Y. Cao, D.Q. Zhu, M.A. Chappell, L.F. Miller, J.D. Mao, Characterization of coals and their laboratory-prepared black carbon using advanced solid-state $\mathrm{C}-13$ nuclear magnetic resonance spectroscopy, Fuel Processing Technology, 96 (2012) 56-64.

[30] M.J. Simpson, P.G. Hatcher, Determination of black carbon in natural organic matter by chemical oxidation and solid-state C-13 Nuclear Magnetic Resonance spectroscopy, Organic Geochemistry, 35 (2004) 923-935.

[31] C. Diaz, C.G. Blanco, NMR: A powerful tool in the characterization of coal tar pitch, Energy \& Fuels, 17 (2003) 907-913.

[32] P. Conte, A. Piccolo, B. van Lagen, P. Buurman, M.A. Hemminga, Elemental quantitation of natural organic matter by CPMAS C-13 NMR spectroscopy, Solid State Nuclear Magnetic Resonance, 21 (2002) 158-170.

[33] S.R. Kelemen, M. Afeworki, M.L. Gorbaty, A.D. Cohen, Characterization of organically bound oxygen forms in lignites, peats, and pyrolyzed peats by X-ray photoelectron spectroscopy (XPS) and solid-state C-13 NMR methods, Energy \& Fuels, 16 (2002) 1450-1462.

[34] W.H. Orem, S.G. Neuzil, H.E. Lerch, C.B. Cecil, Experimental early-stage coalification of a peat sample and a peatified wood sample from Indonesia, Organic Geochemistry, 24 (1996) 111-125.

[35] R.L. Cook, C.H. Langford, R. Yamdagni, C.M. Preston, A modified cross-polarization magic angle spinning C-13 NMR procedure for the study of humic materials, Analytical Chemistry, 68 (1996) 39793986.

[36] J.D. Mao, A. Schimmelmann, M. Mastalerz, P.G. Hatcher, Y. Li, Structural Features of a Bituminous Coal and Their Changes during Low-Temperature Oxidation and Loss of Volatiles Investigated by Advanced Solid-State NMR Spectroscopy, Energy \& Fuels, 24 (2010) 2536-2544. [37] S. Kalaitzidis, A. Georgakopoulos, K. Christanis, A. Iordanidis, Early coalification features as approached by solid state C-13 CP/MAS NMR spectroscopy, Geochimica Et Cosmochimica Acta, 70 (2006) 947-959.

[38] C. Keeler, G.E. Maciel, (13)C NMR spectral editing of humic material, Journal of Molecular Structure, 550 (2000) 297-305.

[39] M. Azik, Y. Yurum, A.F. Gaines, AIR OXIDATION OF TURKISH BEYPAZARI LIGNITE .1. CHANGE OF STRUCTURAL CHARACTERISTICS IN OXIDATION REACTIONS AT 150-DEGREES-C, Energy \& Fuels, 7 (1993) 367-372.

[40] L. Yan, Y. Bai, R. Zhao, F. Li, K. Xie, Correlation between coal structure and release of the two organic compounds during pyrolysis, Fuel, 145 (2015) 12-17.

[41] W. Li, M. Doblinger, A. Vaneski, A.L. Rogach, F. Jackel, J. Feldmann, Pyrite nanocrystals: shapecontrolled synthesis and tunable optical properties via reversible self-assembly, Journal of Materials Chemistry, 21 (2011) 17946-17952.

[42] S. Kar, S. Chaudhuri, Synthesis of highly oriented iron sulfide nanowires through solvothermal process, Materials Letters, 59 (2005) 289-292. 
[43] L. Meng, Y.H. Liu, L. Tian, Evolutions of structure, composition and optical absorption behavior of pyrite films formed by sulfurating iron, Materials Research Bulletin, 38 (2003) 941-948.

[44] D.Y. Wan, B.Y. Wang, Y.T. Wang, H. Sun, R.G. Zhang, L. Wei, Effects of the sulfur pressure on pyrite FeS2 films prepared by sulfurizing thermally iron films, Journal of Crystal Growth, 257 (2003) 286-292.

[45] Y.H. Liu, L. Meng, L. Zhang, Optical and electrical properties of FeS2 thin films with different thickness prepared by sulfurizing evaporated iron, Thin Solid Films, 479 (2005) 83-88.

[46] M.J. Iglesias, G. de la Puente, E. Fuente, J.J. Pis, Compositional and structural changes during aerial oxidation of coal and their relations with technological properties, Vibrational Spectroscopy, 17 (1998) 41-52.

[47] X. Wang, Q. Xiang, B. Liu, L. Wang, T. Luo, D. Chen, G. Shen, TiO2 modified FeS Nanostructures with Enhanced Electrochemical Performance for Lithium-Ion Batteries, Scientific Reports, 3 (2013). [48] J. Ning, Y. Zheng, D. Young, B. Brown, S. Nesic, Thermodynamic Study of Hydrogen Sulfide Corrosion of Mild Steel, Corrosion, 70 (2014) 375-389.

[49] M.J. Roberts, R.C. Everson, H.W.J.P. Neomagus, D. Van Niekerk, J.P. Mathews, D.J. Branken, Influence of maceral composition on the structure, properties and behaviour of chars derived from South African coals, Fuel, 142 (2015) 9-20.

[50] A. Arenillas, F. Rubiera, J.J. Pis, M.J. Cuesta, M.J. Iglesias, A. Jimenez, I. Suarez-Ruis, Thermal behaviour during the pyrolysis of low rank perhydrous coals, Journal of Analytical and Applied Pyrolysis, 68-9 (2003) 371-385.

[51] K. Damen, M. van Troost, A. Faaij, W. Turkenburg, A comparison of electricity and hydrogen production systems with $\mathrm{CO} 2$ capture and storage. Part A: Review and selection of promising conversion and capture technologies, Progress in Energy and Combustion Science, 32 (2006) 215246.

[52] H.Q. Hu, Q. Zhou, S.W. Zhu, B. Meyer, S. Krzack, G.H. Chen, Product distribution and sulfur behavior in coal pyrolysis, Fuel Processing Technology, 85 (2004) 849-861.

[53] W. He, Z. Liu, Q. Liu, M. Liu, X. Guo, L. Shi, J. Wu, X. Guo, D. Ci, Analysis of Tars Produced in Pyrolysis of Four Coals under Various Conditions in a Viewpoint of Radicals, Energy \& Fuels, 29 (2015) 3658-3663.

[54] S. Khare, M. Dell'Amico, An overview of conversion of residues from coal liquefaction processes, Canadian Journal of Chemical Engineering, 91 (2013) 1660-1670.

[55] A.N. Stranges, BERGIUS, FRIEDRICH AND THE RISE OF THE GERMAN SYNTHETIC FUEL INDUSTRY, Isis, 75 (1984) 643-667.

[56] M. Hook, K. Aleklett, A review on coal-to-liquid fuels and its coal consumption, International Journal of Energy Research, 34 (2010) 848-864.

[57] A.S. Maloletnev, M.Y. Shpirt, Present State of Coal Liquefaction Technologies, Russian Journal of General Chemistry, 79 (2009) 2499-2508.

[58] K. Miura, Mild conversion of coal for producing valuable chemicals, Fuel Processing Technology, 62 (2000) 119-135.

[59] K. Du, Y. Li, M. Lian, Analysis of the Factors in Affecting the Performance of Coal Liquefaction, Material Science, Civil Engineering and Architecture Science, Mechanical Engineering and Manufacturing Technology li, 651-653 (2014) 195-199.

[60] M. Rahman, T. Adesanwo, R. Gupta, A. de Klerk, Effect of Direct Coal Liquefaction Conditions on Coal Liquid Quality, Energy \& Fuels, 29 (2015) 3649-3657.

[61] T. Fergoug, Y. Bouhadda, Determination of Hassi Messaoud asphaltene aromatic structure from H-1 \& C-13 NMR analysis, Fuel, 115 (2014) 521-526.

[62] A. Piccolo, P. Conte, E. Trivellone, B. Van Lagen, Reduced heterogeneity of a lignite humic acid by preparative HPSEC following interaction with an organic acid. Characterization of size-separates by Pyr-GC-MS and H-1-NMR spectroscopy, Environmental Science \& Technology, 36 (2002) 76-84.

[63] E. Pretsch, P. Bühlmann, C. Affolter, E. Pretsch, P. Bhuhlmann, C. Affolter, Structure determination of organic compounds, Springer, 2009. 
[64] S. Yani, D. Zhang, An experimental study into pyrite transformation during pyrolysis of Australian lignite samples, Fuel, 89 (2010) 1700-1708.

[65] S. Karaca, Desulfurization of a Turkish lignite at various gas atmospheres by pyrolysis. Effect of mineral matter, Fuel, 82 (2003) 1509-1516.

[66] J.A. Guin, A.R. Tarrer, J.W. Prather, D.R. Johnson, J.M. Lee, EFFECTS OF COAL MINERALS ON HYDROGENATION, DESULFURIZATION, AND SOLVENT-EXTRACTION OF COAL, Industrial \& Engineering Chemistry Process Design and Development, 17 (1978) 118-126.

[67] D. Borah, M. Barua, M.K. Baruah, Dependence of pyrite concentration on kinetics and thermodynamics of coal pyrolysis in non-isothermal systems, Fuel Processing Technology, 86 (2005) 977-993.

[68] S.-Y. Zhang, J.-F. Lu, J.-S. Zhang, G.-X. Yue, Effect of pyrolysis intensity on the reactivity of coal char, Energy \& Fuels, 22 (2008) 3213-3221.

[69] K.K. Robinson, Reaction Engineering of Direct Coal Liquefaction, Energies, 2 (2009) 976-1006. [70] L. Chen, S. Bhattacharya, Sulfur Emission from Victorian Brown Coal Under Pyrolysis, Oxy-Fuel Combustion and Gasification Conditions, Environmental Science \& Technology, 47 (2013) 1729-1734. [71] A. Czaplicki, W. Smolka, Sulfur distribution within coal pyrolysis products, Fuel Processing Technology, 55 (1998) 1-11.

[72] D. Zhang, S. Yani, Sulphur transformation during pyrolysis of an Australian lignite, Proceedings of the Combustion Institute, 33 (2011) 1747-1753. 
Table 1. Air dry lignite analysis results.

\begin{tabular}{|c|c|c|c|c|c|}
\hline \multicolumn{2}{|c|}{ Proximate Analysis } & \multicolumn{2}{|c|}{ Elemental Analysis } & \multicolumn{2}{|c|}{ Eshka Analysis of Sulfur compounds } \\
\hline Coal basics & Weight $\%$ & Elements & Weight $\%$ & $\begin{array}{l}\text { Sulfur } \\
\text { compound } \\
\end{array}$ & Weight $\%$ \\
\hline Moisture & $4.7 \pm 0.9$ & Carbon & $37.7 \pm 0.7$ & Total sulfur & $3.9 \pm 0.2$ \\
\hline Ash & $37.9 \pm 0.2$ & Hydrogen & $3.6 \pm 0.1$ & Pyritic sulfur & $2.6 \pm 0.1$ \\
\hline $\begin{array}{l}\text { Volatile } \\
\text { matter }\end{array}$ & $27.9 \pm 0.1$ & Nitrogen & $1.6 \pm 0.1$ & Sulfates & $1.2 \pm 0.1$ \\
\hline $\begin{array}{l}\text { Fixed } \\
\text { carbon }\end{array}$ & $29.5 \pm 0.1$ & Sulfur & $5.4 \pm 0.6$ & Organic sulfur & $0.1 \pm 0.1$ \\
\hline
\end{tabular}


Table 2. Inorganic composition of "air-dried" lignite and its ash determined by XRF.

\begin{tabular}{lll}
\hline Inorganic compound & Ash analysis $(\mathrm{Wt} \%)$ & Lignite Analysis $(\% \mathrm{Wt})$ \\
\hline $\mathrm{SiO}_{2}$ & $53.6 \pm 0.4$ & 35.08 \\
$\mathrm{Fe}_{2} \mathrm{O}_{3}$ & $13.0 \pm 0.1$ & 9.97 \\
$\mathrm{Al}_{2} \mathrm{O}_{3}$ & $24.9 \pm 0.2$ & 16.70 \\
$\mathrm{MgO}$ & $1.9 \pm 0.1$ & 1.29 \\
$\mathrm{CaO}$ & $0.8 \pm 0.0$ & 0.43 \\
$\mathrm{Na}_{2} \mathrm{O}$ & $0.1 \pm 0.0$ & $<0.1 \pm 0.0$ \\
$\mathrm{~K}_{2} \mathrm{O}$ & $1.2 \pm 0.0$ & 0.61 \\
$\mathrm{~B}_{2} \mathrm{O}_{3}$ & $2.2 \pm 0.1$ & $<0.1 \pm 0.0$ \\
$\mathrm{SO}_{3}$ & $0.9 \pm 0.1$ & 15.54 \\
\hline
\end{tabular}


Table 3. Total amount of $\mathrm{CH}_{4}, \mathrm{H}_{2}$, and $\mathrm{CO}_{2}$ obtained during temperature programmed pyrolysis under nitrogen flow and temperature programmed oxidation under air flow.

\begin{tabular}{|l|l|l|}
\hline Product & $\begin{array}{l}\text { Amount formed } \\
\text { during } \\
\text { temperature } \\
\text { programmed } \\
\text { pyrolysis } \\
\text { (mmol/gcoal) }\end{array}$ & $\begin{array}{l}\text { Amount formed } \\
\text { during } \\
\text { temperature } \\
\text { programmed } \\
\text { oxidation } \\
\text { (mmol/gcoal) }\end{array}$ \\
\hline $\mathrm{CH}_{4}$ & 1.79 & 0.082 \\
\hline $\mathrm{H}_{2}$ & 3.38 & 0.022 \\
\hline $\mathrm{CO}_{2}$ & 2.91 & 37.11 \\
\hline
\end{tabular}


Table 4. Elemental Analysis results of pure coal, pyrolysis char and hydrogenation char.

\begin{tabular}{|c|c|c|c|c|l|l|}
\hline & & & & & $\begin{array}{l}\text { Volatile } \\
\text { content } \\
\text { after } \\
\text { pyrolysis in } \\
\text { TGA }(\%)\end{array}$ & $\begin{array}{l}\text { Ash } \\
\text { content } \\
\text { after air } \\
\text { oxidation } \\
\text { in TGA }\end{array}$ \\
& $\mathrm{C}(\%)$ & $\mathrm{H}(\%)$ & $\mathrm{N}(\%)$ & $\mathrm{S}(\%)$ \\
\hline Unprocessed lignite & 38.0 & 3.6 & 1.6 & 5.4 & 28 & 39 \\
\hline Pyrolysis char & 39.7 & 1.1 & 1.2 & 3.9 & 19 & 59 \\
\hline Hydrogenation char & 38.8 & 0.7 & 0.6 & 0.5 & 5 & 64 \\
\hline
\end{tabular}


Table 5. Compounds identified from post reaction analysis of collected tar residues through ${ }^{1} \mathrm{H}$ NMR of the extracted compounds from tar and char.

\begin{tabular}{|c|c|c|c|c|c|}
\hline \multirow[t]{2}{*}{$\begin{array}{l}\text { Processing } \\
\text { conditions }\end{array}$} & \multirow{2}{*}{$\begin{array}{l}\% \\
\text { volatiles } \\
\text { (from } \\
\text { TGA in } \\
\mathrm{N}_{2} \text { ) }\end{array}$} & \multirow{2}{*}{$\begin{array}{l}\% \\
\text { ash } \\
\text { (from } \\
\text { TGA } \\
\text { in } \\
\text { Air) }\end{array}$} & \multicolumn{3}{|c|}{$\begin{array}{l}\text { Assignments and relative intensities of }{ }^{1} \mathrm{H} \\
\text { NMR peaks of the extracts in DMSO }[22,61 \text { - } \\
63]\end{array}$} \\
\hline & & & $\begin{array}{l}\text { Aromatics } \\
(\sim 7.4 \mathrm{ppm} \\
\text { from TMS })\end{array}$ & $\begin{array}{l}\text { Alkyl }\left(-\mathrm{CH}_{3}\right) \\
(0.83 \text { ppm from } \\
\text { TMS) }\end{array}$ & $\begin{array}{l}\text { Alkyl }\left(-\mathrm{CH}_{2-}\right) \\
(1.23 \mathrm{ppm} \\
\text { from TMS })\end{array}$ \\
\hline $\begin{array}{l}\text { Unprocessed } \\
\text { Lignite }\end{array}$ & 32 & 38 & 0.64 & 0.14 & 0.22 \\
\hline Pyrolysis tar & 19 & 59 & 0.55 & 0.12 & 0.33 \\
\hline $\begin{array}{l}\text { Atmospheric } \\
\text { pressure } \\
\text { hydrogenation } \\
\text { tar }\end{array}$ & 5 & 62 & 0.76 & 0.20 & 0.04 \\
\hline
\end{tabular}




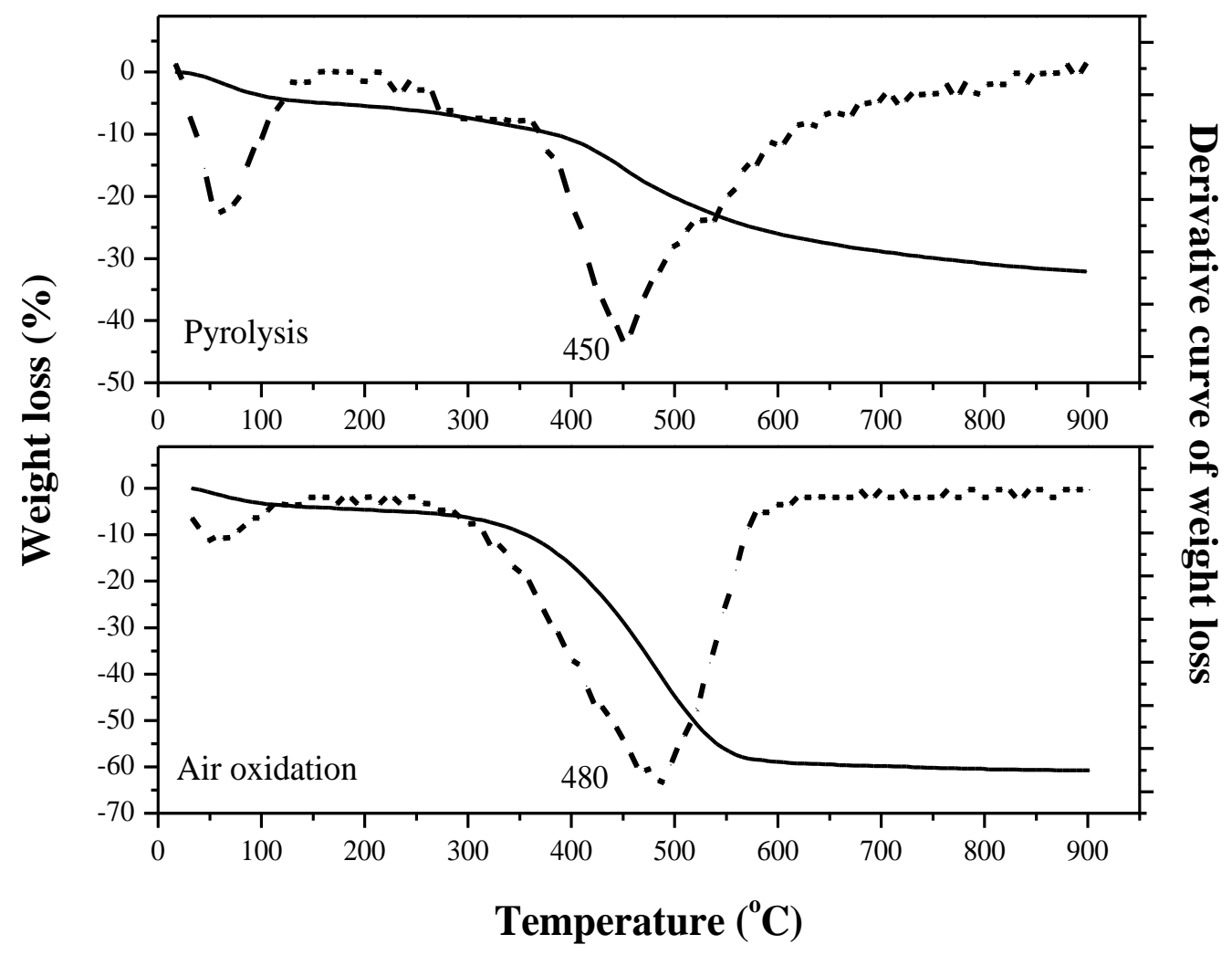

Figure 1. TGA and DTG curves of coal sample under $\mathrm{N}_{2}$ flow (a) and air flow (b). Solid line represents the TGA, while dotted line represents the DTG. 


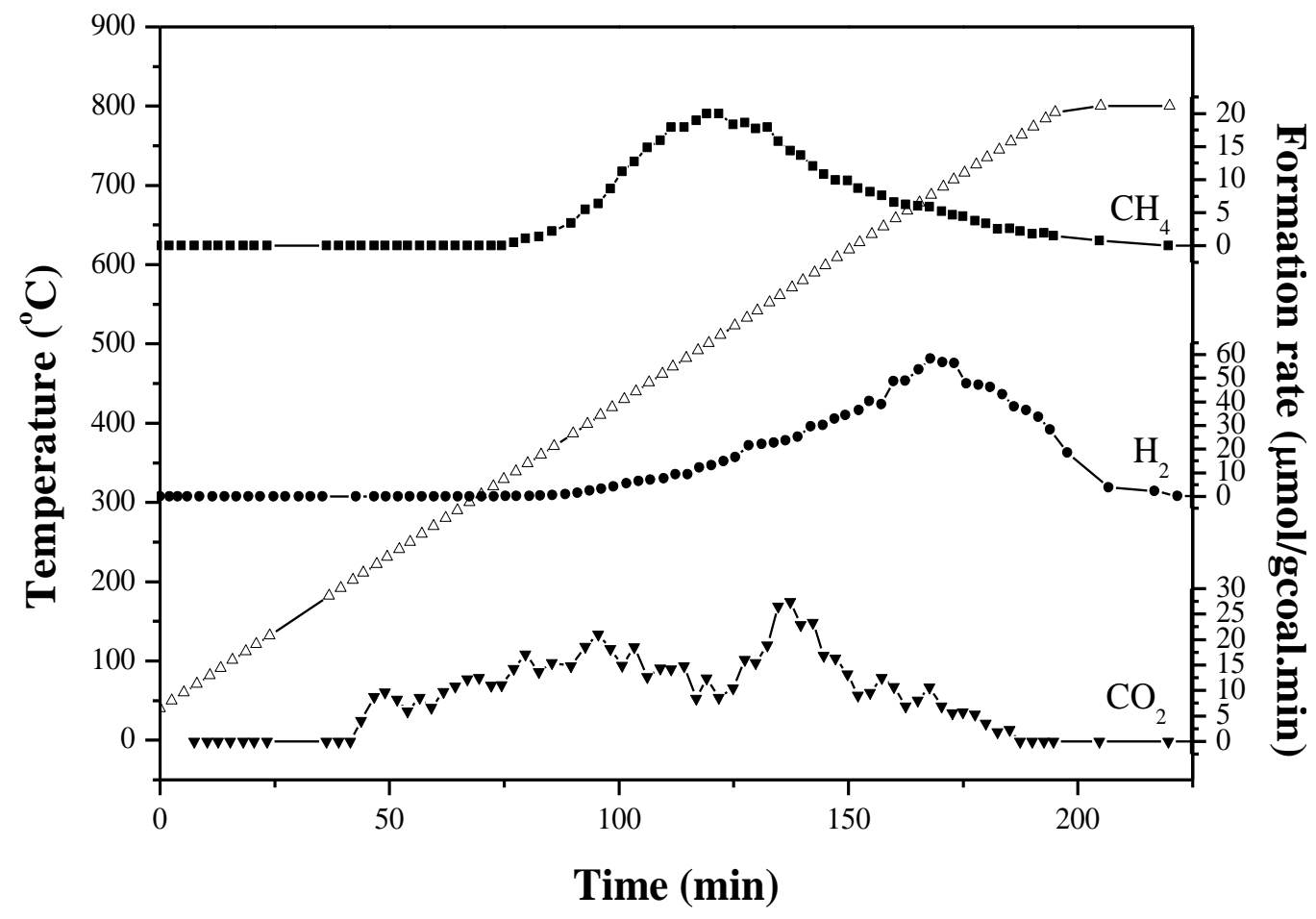

Figure

2. $\mathrm{CH}_{4}, \mathrm{H}_{2}$ and $\mathrm{CO}_{2}$ formation rates under $\mathrm{N}_{2}$ flow. 


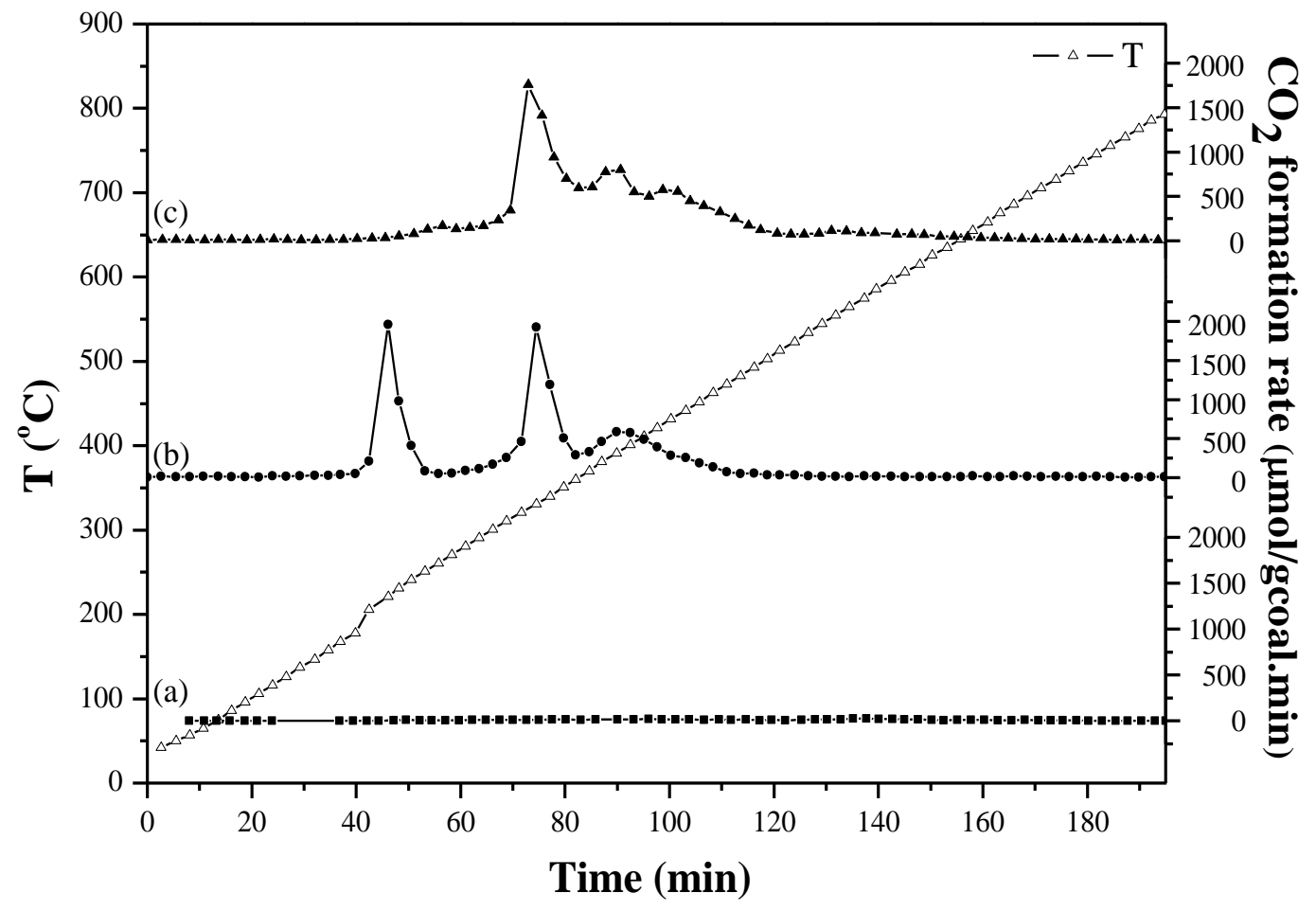

Figure 3. Comparison of $\mathrm{CO}_{2}$ formation rate during pyrolysis (a), oxidation of parent coal (b), and oxidation of pyrolysis char (c). 
(c)

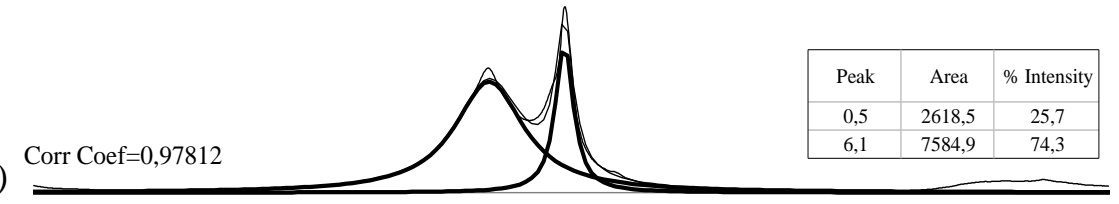

(b) Corr Coef $=0,99312$

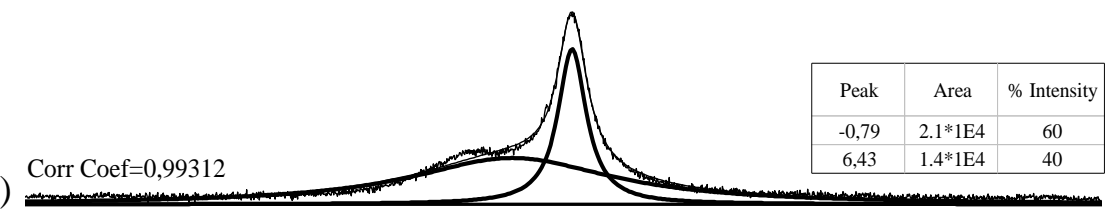

(a)

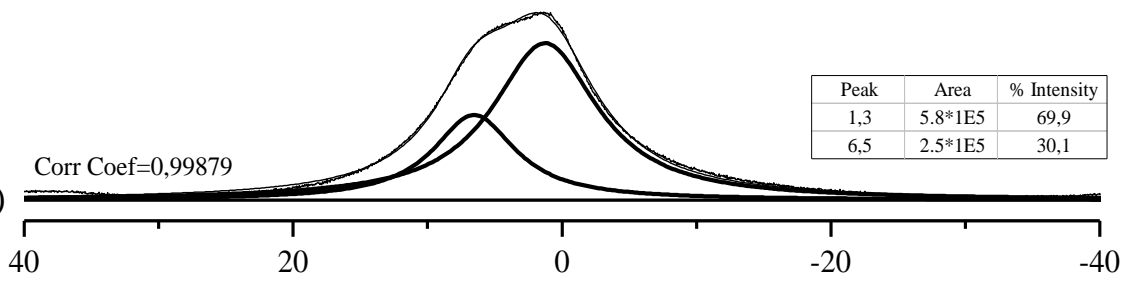

${ }^{1} \mathrm{H}$ shift (ppm from TMS)

Figure 4. ${ }^{1} \mathrm{H}$ NMR spectra of (a) unprocessed Tuncbilek lignite, (b) its pyrolysis char, and (c) its hydropyrolysis tar. 
(c)

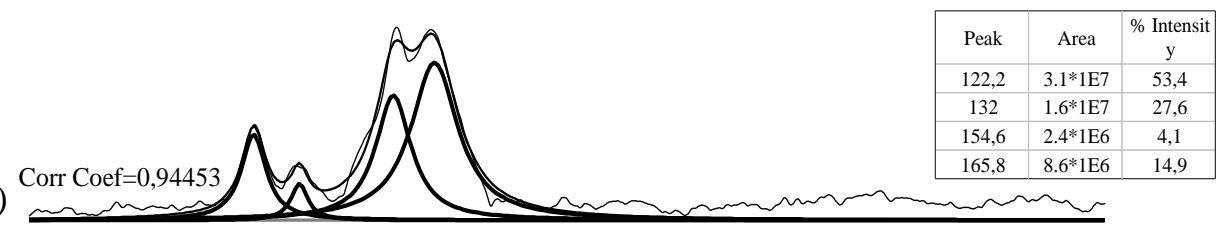

(b)

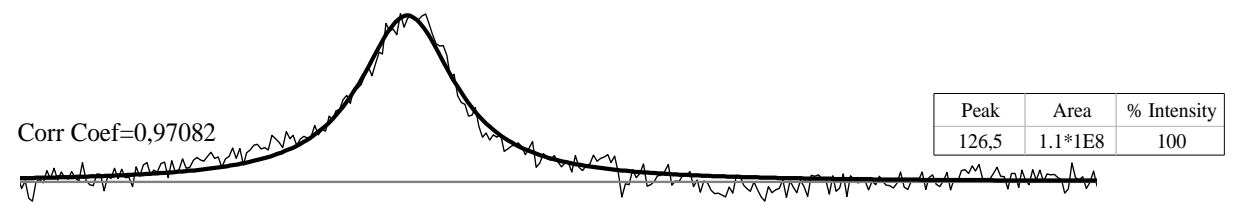

(a)

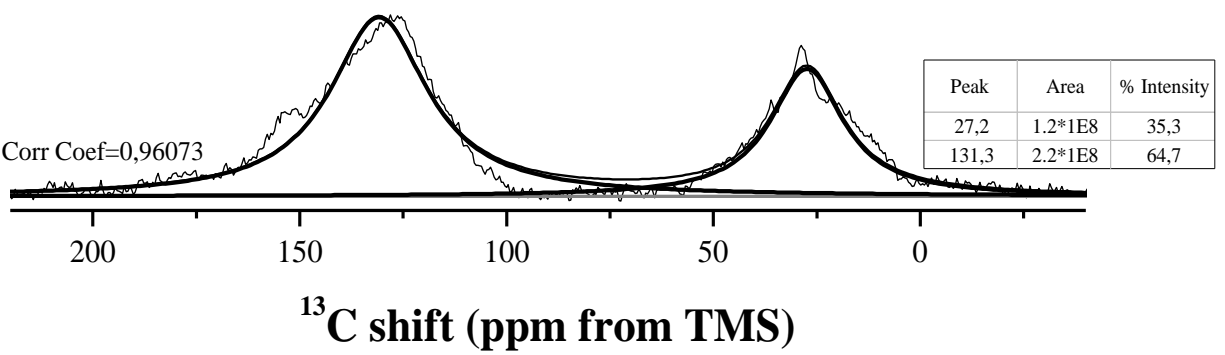

Figure $5 .{ }^{13} \mathrm{C}(\mathrm{CP})$ MAS NMR spectra of (a) unprocessed Tuncbilek lignite, (b) its pyrolysis char, and (c) its hydropyrolysis tar. 
(c)

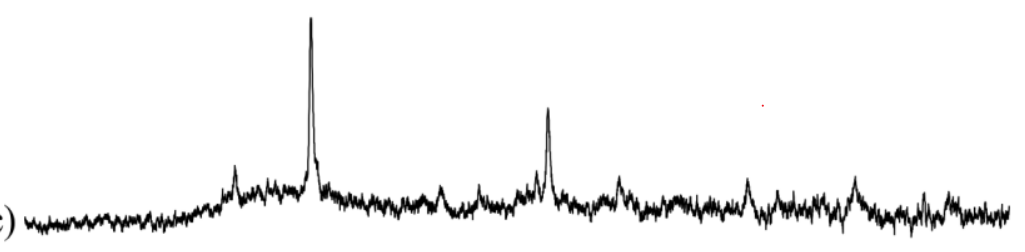

(b)
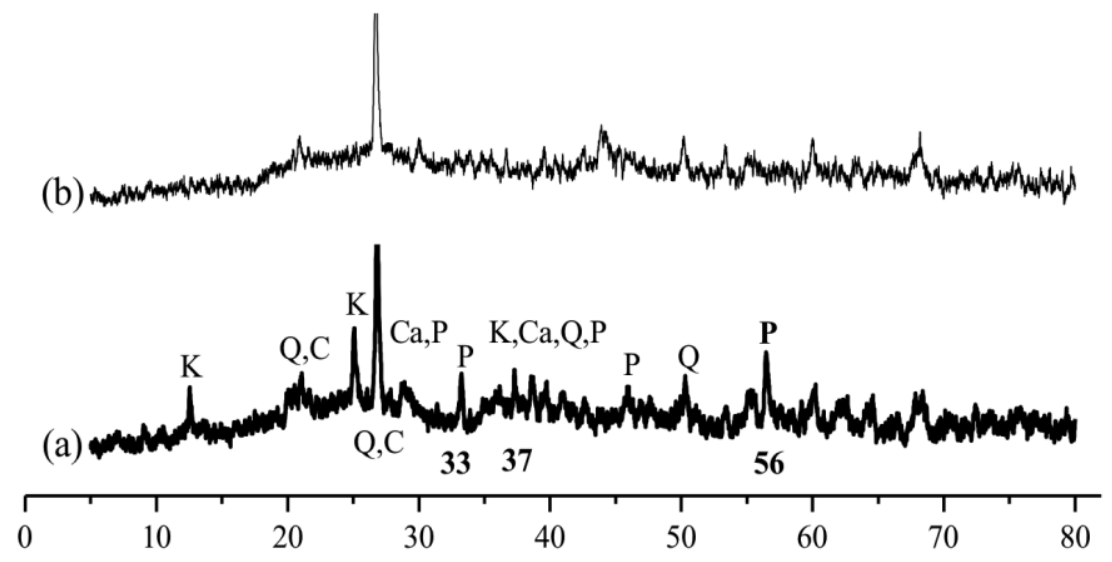

Q: Quartz K: Kaolinite $\quad 2 \theta$

Ca: Calcite P: Pyrite

C: Carbon

Figure 6. XRD patterns of (a) unprocessed lignite, (b) pyrolysis char, and (c) hyropyrolysis char of Tuncbilek lignite. 


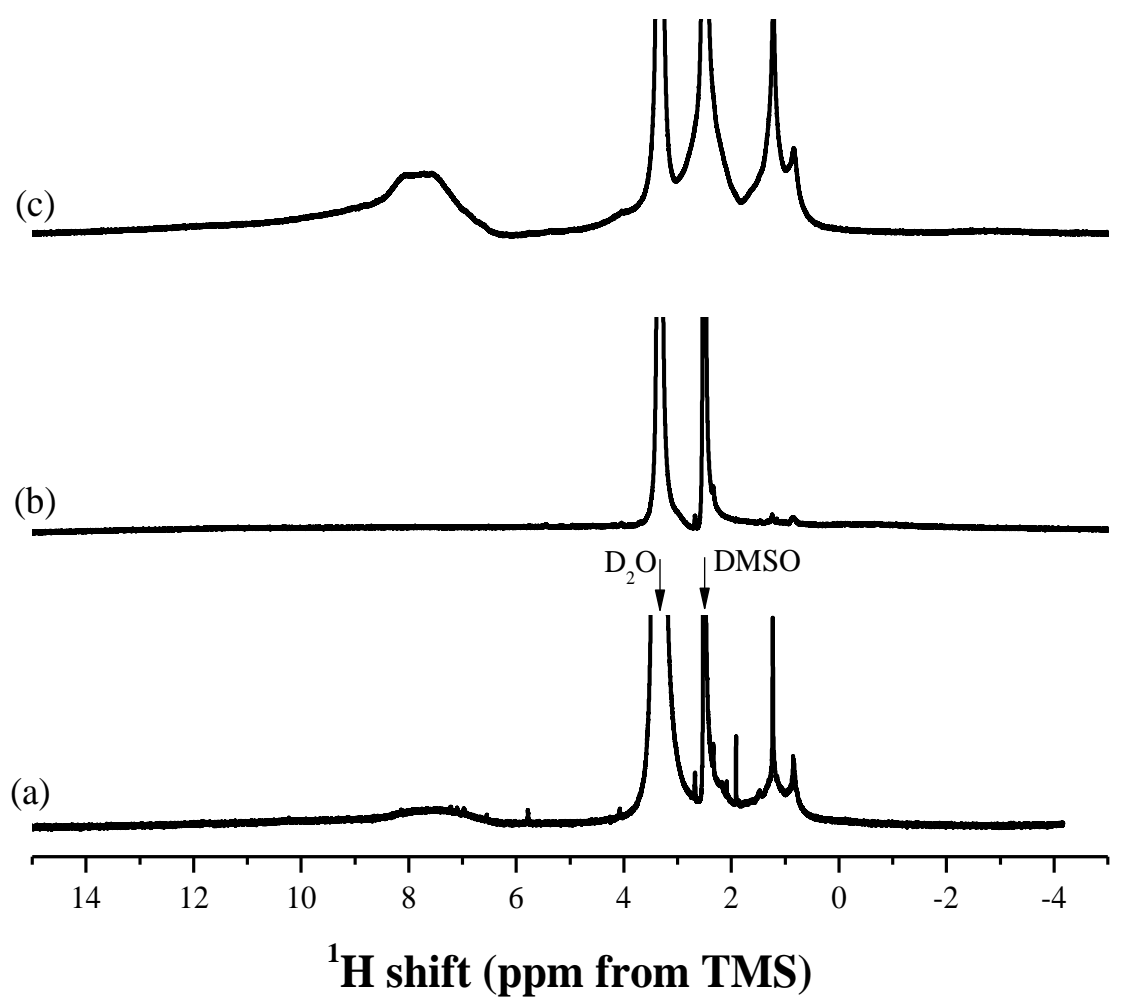

Figure 7. Liquid ${ }^{1} \mathrm{H}$ NMR spectra of the components extracted in DMSO of (a) unprocessed Tuncbilek lignite, (b) its pyrolysis char, and (c) its hydropyrolysis tar. 